\title{
Two Years Trend of Cervical Screening and Precancerous and Cancerous Lesion in Cervical Biopsy inParopakar Maternity and Women's Hospital
}

\author{
Karishma Malla Vaidya, ${ }^{1}$ Gehanath Baral, ${ }^{2}$ Bigya Shrestha ${ }^{1}$ \\ ${ }^{1}$ Department of Pathology, ${ }^{2}$ Department of Obstetrics \& Gynecology
}

Received: 30 November 2018; Accepted: 20 October 2018

DOI: $10.3126 /$ njog.v13i3.23430

ABSTRACT

Aims: To determine the detection rate of cervical lesion by cervical Pap test and to see the ongoing trend of Pap testing in the hospital.

Methods: The retrospective study was conducted in department of pathology, Paropakar Maternity and Women's Hospital, Thapathali, Kathmandu, Nepal from 2016 to 2018. Pap testing sample received in the department were included in the study. All the data were retrieved from computers and registersat record section and histopathology unit.

Results: There were $5.49 \%$ (1688 out of 30725) and 6.12\% (1779 out of 29062) of gynecology out-patients had Pap test in first and second year respectively.Epithelial cells abnormalities were seen in $6.1 \%(104)$ and $4.83 \%(86)$ in first and second year respectively.Cervical biopsy sample in first year and second year had precancer and cancerous lesion in 29.55\% (94 out of 318) and 22.01\% (59 out of 268) in second year.

Conclusions: Epithelial abnormalities seen in Pap test could detect quite a good proportion of abnormal cervical lesion in biopsy specimen of cervix.

Keywords: cervical biopsy, cervical cancer, cervical intraepithelial neoplasm, cervical screening.

\section{INTRODUCTION}

Cervical cancers have increased from an estimated 378000 in 1980 to 5000000 per year in recent years, reflecting an average annual increase of $0.6 \%{ }^{1}$ According to ACOG guidelines cervical screening done for women in every three years, iftest isdone alone. If women have a Pap test along with HPV test (co-testing) then every 5 years interval. After Papanicolaou (Pap) test was implemented in the United States, cervical cancer mortality rates have declined by $74 \% .2$ Developing countries do not have ample of resources to implement cytology based prevention programs. Incidence and mortality related to cervical cancer are both declining in developed countries because of effective screening programmers' of Papanicolaou test. ${ }^{3}$ Cervical cancer is the most common cancer in women and about 500 thousand women annually in the developing world lose their lives to this cancer. ${ }^{4}$
Our study was intended to see ongoing trend of Papsmear testing in our hospital with that of cervical biopsy specimen with positive for intraepithelial lesion and cervical cancer within that period.

\section{METHODS}

It was a retrospective descriptive study of Pap tests and cervical biopsy specimens received at Department of Pathology during two years period from 2016-April-13 to 2018-April-13 at Paropakar Maternity and Women's Hospital, Kathmandu. Out of 59787 gynaecology outpatients 3467 Pap test samples received and reported according to Bethesda System.5Screened samples with epithelial abnormalities were recorded from the department'sfiles and computers. There were 586 cervical biopsy specimens the samples showing intraepithelial neoplasm and malignancies wererecorded.

\section{CORRESPONDENCE}

Dr. Karishma Malla Vaidya

Paropakar Maternity and Women's Hospital, Thapathali,

Kathmandu, Nepal.

Email: rupkari@yahoo.com; Phone:+977941449234 


\section{RESULTS}

In this study, total no of gynecology cases seen in two years period (2016-April-13 to 2018-April-13) was 59,787. Record was traced from static department and pathology department of the hospital. Total no of Gynecology case seen in Out Patient Department 2016- April-13 to 2017-April- 1 was 30725 where as in 2017-April-13 to 2018-April-13, gynecology case seen in OPD was 29062. Within that period total numbers of Liquid based Pap smear was seen 3250 and conventional Pap smear was seen 217. So altogether Pap smear tests interpreted were 3467, i.e. 5.79\% of total gynecology case in the OPD [Figure 1 and 2].

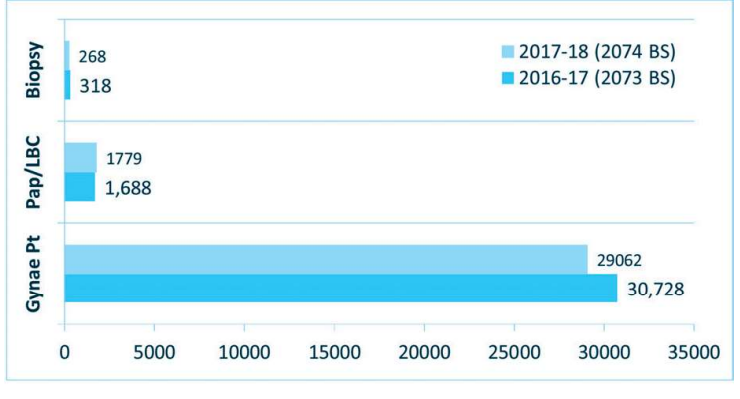

Figure 1: Two years' trend in cervical screening.

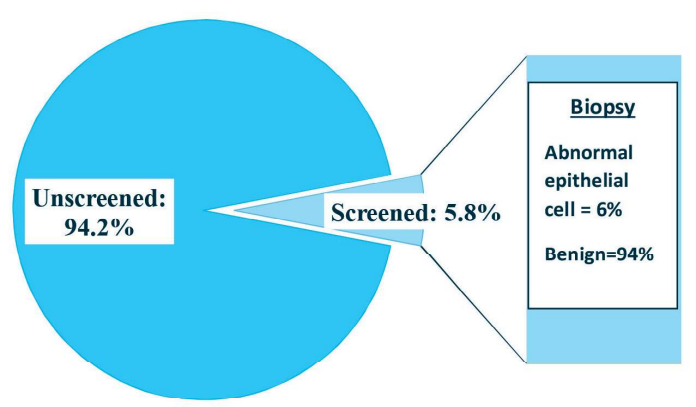

Figure 2: Screening and epithelial cell abnormality $(n=3467)$.

Among these cervical screening testssquamous abnormalities were seen in 203 cases and 7 cases were interpreted as squamous cell carcinoma i.e. $6.01 \%$ of all pap screen test showed precancerous and cancerous lesion [Figure-3].

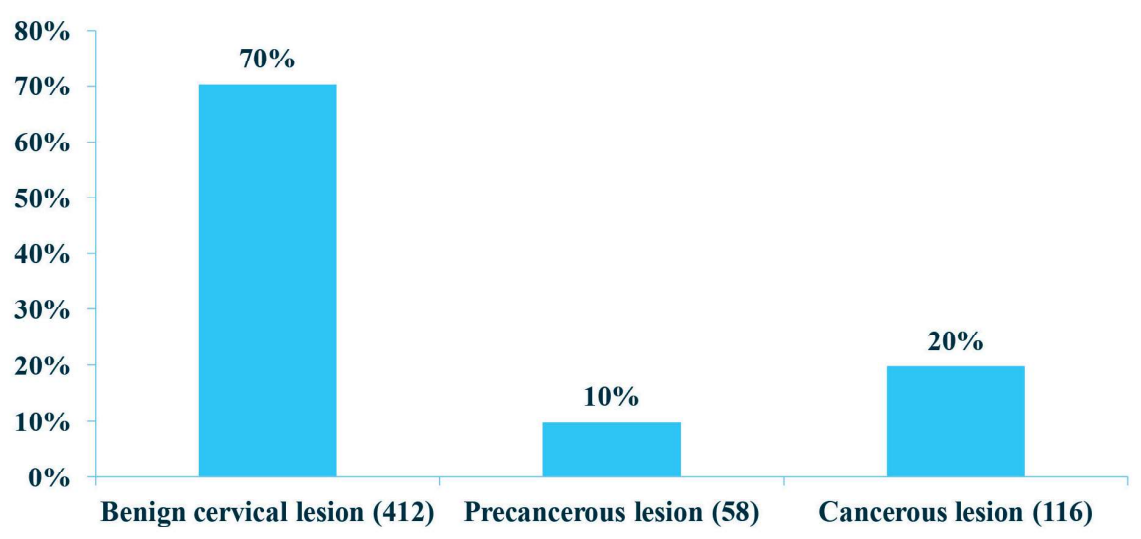

Figure 3: Cervical biopsy lesions $(\mathbf{n}=\mathbf{5 8 6})$.

The cervical biopsy specimenreceived in histopathology department was 586. Among these biopsy specimen precancerous and cancerous lesion were seen in 174 cervical biopsy tissue i.e. $29.6 \%$ of all cervical biopsy specimen showed precancerous lesion and cancerous lesion; $66.6 \%$ showed cancerous lesion among all precancerous and cancerous lesion.

\section{DISCUSSION}

Most cases of cervical cancer (85\%) occur in developing countries that have ineffective screening programs. ${ }^{6}$ Because of opportunistic screening practice at this hospital, the screen positivity is more than the proportion of screened population. Whereas the study done by Siegel et al showed cervical cancer-related deaths in American women declined by more than $80 \%$ from 1930 to 2012, primarily because of widespread use of cytology (Papanicolaou [Pap] test). ${ }^{7}$ Today, with proper implementation of the pap smear many cases of cervical cancer can be detected. 
The role of Papanicolaou (Pap) smear as a cancer screening tool for cervix has been substantiated by several studies in the last 50 years and the methods has resulted in falling incidence and mortality of cervical cancer in developed world. ${ }^{8}$ As the British women screened by $85 \%$, the incidence of cervical cancer has decreased by $75 \% .{ }^{9}$ In Norway, where only about $5 \%$ of women are screened, the incidence of cervical cancer increased during the same time period. ${ }^{10-12}$

We have detected $6 \%$ of epithelial abnormalities (including ASCUS, AGUS, ASC-H, LSIL, HSIL and squamous cell carcinoma) among all the women that has been screened but the studies done in India and Pakistan showedlittle lower in its prevalence rate. ${ }^{13-15}$

In the Practice Bulletins- Gynecology they have mentioned nearly one-half of women with cervical cancer were not screened before diagnosis, and another $10 \%$ were not screened within the previous five years. ${ }^{16}$ Pap screening is done to find abnormal cervical cytology-cervical dysplasia \& cervical cancers in population. Routine cytological screening would go a long way in the early detection of cervical dysplasia and help in reducing the incidence of cervical cancer. Though, the definite method to diagnose cervical cancer is biopsy.17-20

\section{CONCLUSIONS}

In the clinical set up like ours less numbers of women were tested for pap testing, who were visited in the hospital with gynecology problem. But the women who underwent cervical biopsy were detected with more intraepithelial dysplasia and cancer of the cervix. Thus the routine screening would help detecting cancer early over opportunistic screening practices.

\section{REFERNCES}

1. Kurman RJ, Carcangiu ML, Herrington CS, Young RH, (Eds): WHO Classification of Tumors of Female Reproductive Organs, 4th ed. Tumors of uterine Cervix.176-7

2. Armstrong EP. Prophylaxis of cervical cancer and related cervical disease: a review of the cost-effectiveness of vaccination against oncogenic HPV types. J Manag Care Pharm. 2010;16(3):217-30

3. Mahmud G, Tasnim N, Iqbal S. Comparison of visual Inspection with acetic acid and Pap smear in cervical cancer screening at tertiary care hospital. J Pak Med Assoc. 2013;63(8)

4. Mojgan KZ, Peighmbari F, Karimi N, Rohi M, Chiti Z. A Comparison of 3 Ways of Conventional Pap Smear, Liquid Based Cytology and Colposcopy vs Cervical Biopsy for Early Diagnosis of Premalignant Lesions or Cervical Cancer in Women with Abnormal Conventional Pap Test. International journal of biomedical science. 2013;9(4). URL:www.ijbs.org

5. Solomon D, Davey D, Kurman R, Moriarty A, O'Connor D, Prey M,et al. Forum Group Members ,Bethesda2001 Workshop. The 2001 Bethesda system: Terminology for reporting results of cervical cytology. JAMA. 2002;287:2114-

6. Martin-Hirsch PL, Wood NJ. Cervical cancer. BMJ Clin Evid 2011. URL: http:// clinical evidence.bmj.com/x/systematicreview/0818/overview.html.[Accessed February 20, 2017].

7. Siegel RL, Miller KD, Jemal A. Cancer statistics 2017. CA Cancer J Clin. 2017;67(1):7-30.

8. Gupta S, Iyengar S, Jain B. Trend of Cervical Dysplsia And Cervical Cancer -in Papanicolaou Smears in Perimenopausal Females In Tertiary Care Centre.IOSR Journal of Dental and Medical Sciences. 2017;16(1):10-3. URL:www.iosrjournals org

9. Marcus C. Pap Test frequency: still controversial. Can Med Assoc J. 1984;130;137-5
10. Editorial. Cancer of the cervix: death by incompetence. Lancet $1985 ; 2: 363-4$

11. Frame PS. A critical review of adult health maintenance. Part 3: prevention of cancer. J Faim Practice. 1986;22:511 -20

12. 12. Draper GJ, Cook GA. Changing patterns of cervical cancer rates. Br Med J. 1983;287:510-12.

13. Mulay K, Swain M, Patra S, Gowrishankar S. A Comparative study of cervical smears in Urban Hopital in India and a population-based screening program in Mauritius. India J Patholol Microbiol. 2009;52:34-7.

14. Baram A, Galon A, Schachter A. Premalignant leions and microinvasion carcinoma of cervix in Jwish women. An epidemiological study. Br J Obstet Gynecol Scand. 1985;92:4-

15. Committee on Practice Bulletins-Gynecology. Practice bulletin no. 168: cervical cancer screening and prevention Obstet Gynecol. 2016;128(4):e111-e130.

16. Wasti S, Ahmed W, Jafri A, Khan B, Sohail R, Hassan S Analysis of cervical smear in Muslim population. Ann Saudi Med. 2004;24:189-92.

17. Addis LB, Hatch KD, Berek JS. Intraepithelial disease of the cervix, vagina, and vulva in: Berek \& Novak's Gynecology, 14th ed. Philadelphia Lippincott co. 2006;1:561-601.

18. Gray W, Mckee G. Diagnostic Cytopathology. 2nd ed London: Churchill Livingstone. 2003; p755-765

19. Kumar V, Fausto N, Abbas A. Robbins \&Cotran Pathologic Basis of Disease, 7th ed. Elsevier Saunders. 2004; p10731075 .

20. Mills SE, Carter D, Gresson JK. Sternberg's diagnostic Surgical pathology,4th ed. Lippincott Williams and Wilkins. 2004:2:2377-8. 